\title{
Pengenalan Oximeter sebagai Deteksi Kejenuhan Oksigen dalam Darah Kepada Satgas Covid-19 Kalurahan Serut, Gunung Kidul
}

\author{
Umi Salamah ${ }^{4^{*}}$, Damar Yoga Kususma² \\ 1,2 Program Studi Fisika Fakultas Sains dan Teknologi Terapan Universitas Ahmad Dahlan Yogyakarya
}

\section{ARTICLE INFO}

Riwayat Artikel:

Draft diterima: 16 November 2021

Revisi diterima: 10 Desember 2021

Diterima: 20 Desember 2021

Tersedia Online: 27 Desember 2021

Corresponding author:

*umi.salamah@fisika.uad.ac.id

Citation: Salamah. U, dan Kususma. D. Y. 2021. Pengenalan Oximeter sebagai Deteksi Kejenuhan Oksigen dalam Darah Kepada Satgas Covid-a9 Kelurahan Serut, Gunung Kidul. ICOMES: Indonesian Journal of Community Empowerment and Service. 1(1), pp: 26-29.

\begin{abstract}
ABSTRAK
Sejak munculnya Covid-19 di Indonesia awal tahun 2020 telah menyebar di seluruh wilayah Indonesia termasuk daerah pedesaan. Kalurahan Serut yang merupakan wilayah perbatasan yaitu kabupaten Klaten dengan Gunung Kidul, tidak lepas dari penyebaran Covid-19. Kondisi masyarakat Kalurahan Serut yang merupakan masyarakat pedesaan tulen menyebabkan kurang memahami bahaya virus tersebut. Simpang siurnya berita di media massa maupun sosial media menjadikan pemahaman tentang Covid-19 ini menjadi kabur. Salah satunya adalah teknologi sistem deteksi kejenuhan oksigen dalam darah secara non-invasif menggunakan oximeter untuk memonitoring kondisi kesehatan darah. Hal ini sangat penting dilakukan terutama pasien yang sudah terkonfirmasi Covid-19 dan menjalani isolasi mandiri di rumah. Dalam pengabdian ini, tim pelaksana bekerja sama dengan pemerintah Kalurahan Serut beserta jajaran satgas Covid-19 untuk mitigasi Covid-19 di wilayah Kalurahan Serut. Adapun Program yang akan dilaksanakan antara lain pemberian materi dan demo deteksi kejenuhan oksigen dalam darah menggunakan oximeter kepada satgas Covid-19. Pemberian materi dan demo tersebut akan dilanjutkan dengan pengambilan sampling data dan analisis kepada masyarakat Kalurahan Serut. Program ini bertujuan untuk mengenalkan sistem pengukuran saturasi oksigen dalam darah dan bagaimana mengukurnya secara mandiri. Hal tersebut sangat penting dilakukan mengingat saturasi oksigen dalam darah menjadi salah satu parameter pada pasien Covid-19.
\end{abstract}

Kata kunci: Oximeter, Kejenuhan Oksigen Darah, satgas Covid-19,

\begin{abstract}
Since the emergence of Covid-19 in Indonesia in early 2020, it has spread throughout Indonesia, including rural areas. The Serut District, which is a border area, namely the Klaten district with Gunung Kidul, cannot be separated from the spread of Covid-19. The condition of the people of Serut Village, which is a genuine rural community, causes a lack of understanding of the dangers of the virus. The confusion of news in the mass media and social media has made the understanding of Covid-19 blurry. One of them is a non-invasive oxygen saturation detection system technology using an oximeter to monitor blood health conditions. This is very important, especially for patients who have confirmed Covid-19 and are self-isolating at home. In this service, the implementing team collaborates with the Serut Village government and the ranks of the Covid-19 task force to mitigate Covid-19 in the Serut Village area. The programs that will be implemented include providing materials and demonstrations for detecting oxygen saturation in the blood using an oximeter to the Covid-19 task force. The provision of materials and demonstrations will be continued with data sampling and analysis to the people of Serut Village. This program aims to introduce the system of measuring oxygen saturation in the blood and how to measure it independently. This is very important considering that oxygen saturation in the blood is one of the parameters in Covid-19 patients.
\end{abstract}

Keywords: Oximeter; Blood Oxygen Saturation ;Satgas Covid-19; Kalurahan Serut

\section{PENDAHULUAN}

Wabah Covid-19 menjadi masalah serius baik nasional maupun global saat ini. Covid-19 mengejutkan dunia dengan berbagai gejala yang belum dikenal masyarakat sebelumnya. Virus ini termasuk virus yang mematikan yang menyebar 
secara massif dari manusia satu ke manusia lain. Oleh sebab itu, penyebaran penyakit ini telah memberikan dampak luas secara sosial dan ekonomi (Susilo et al., 2020). Kajian tentang virus ini masih belum menemukan kepastian dalam menghentikan pendemi akibat virus ini (Syafrida and Hartati, 2020).

Kalurahan Serut merupakan wilayah perbatasan antara Gunung Kidul dengan Kabupaten Klaten juga tidak luput dari penyebaran Covid-19. Masyarakat Kalurahan Serut yang notabenenya adalah masyarakat desa tulen dengan pengetahuan mitigasi Covid-19 sangat minim. Salah satu pengetahuan yang penting untuk mitigasi Covid-19 adalah deteksi kejenuhan oksigen dalam darah bagi pasien yang terinfeksi Covid-19 dan melakukan isolasi mandiri. Instrumentasi yang digunakan untuk deteksi oksigen dalam darah tersebut adalah oximeter, dengan oximeter tersebut dapat menentukan seseofrang megalami kekurangan oksigen dalam darah (hipoksemia) atau dalam kondisi normal (Sinex, 1999; Smith Medical PM, 2007; Njoum and Kyriacou, 2013; Salamah, 2016). Oximeter digital telah banyak beredar di pasaran, namun dalam penggunaannya diperlukan pengetahun tentang oksigen dalam darah, bagaimana cara penggunaannya dan membaca hasil pengukurannya. Dalam pengabdian ini, dilakukan pengenalan oximeter, edukasi tentang kadar oksigen dalam darah dan juga demo bagaimana penggunaan oximeter. Peserta dalam pengabdian ini adalah Satgas Covid Kalurahan Serut yang terdiri dari pemerintah Kalurahan Serut dan tim relawan.

\section{METODE PELAKSANAAN}

Metode pelaksanaan yang akan digunakan pada pengabadian kepada masyarakat ini adalah :

a. Pemberian materi tentang kejenuhan oksigen dalam darah, oximeter dan parameter-parameter dalam pembacaan oximeter.

b. Pemberian demo kepada peserta, memberikan simulasi penggunaan oximeter dan bagaimana menyimpulkan hasil pengukurannya.

c. Sampling dan analisis data, melakukan pengujian sampel data pada semua peserta.

d. Evaluasi, melakukan evaluasi tentang pemahaman tentang oximeter dengan memberikan pre test dan post test.

\section{HASIL DAN PEMBAHASAN}

Pengabdian ini dilakukan dengan pemberian pretest tentang pemahaman seputar kadar kejenuhan oksigen dalam darah. Pretest tersebut berisi 10 pertanyaan, capture soal pre test ditunjukan pada Gambar 1. Sedangkan, hasil dari pretest ditampilkan pada Tabel 1.
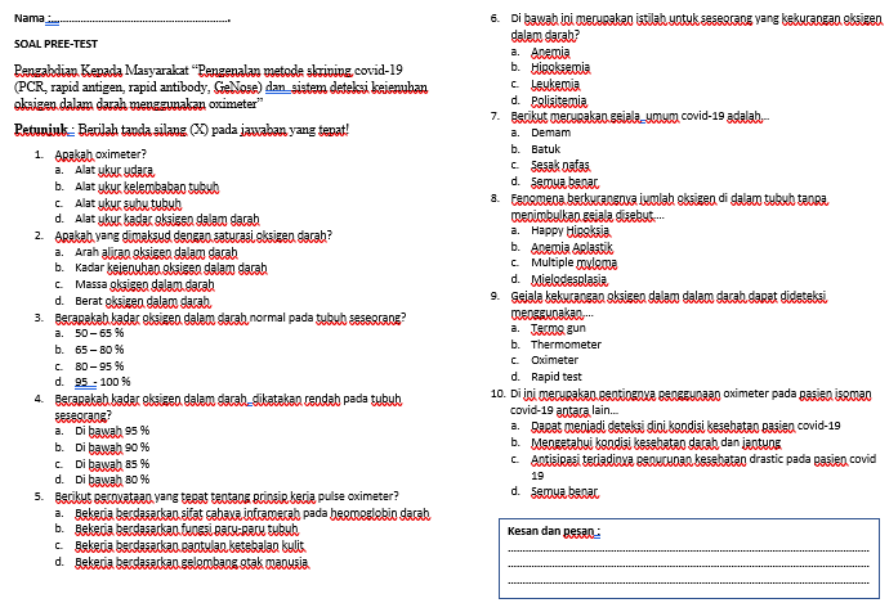

Gambar 1. Capture soal pre-test

Tabel 1. Hasil pretest peserta pengabdian

\begin{tabular}{|c|c|c|}
\hline No & Nama Peserta & Penilaian \\
\hline 1 & Nana & 60 \\
\hline 2 & Sigit Purnomo & 70 \\
\hline 3 & Triyono & 70 \\
\hline 4 & Nurul Hidayah & 50 \\
\hline 5 & Muji Rahayu & 50 \\
\hline 6 & Harsini & 60 \\
\hline 7 & Dariyem & 60 \\
\hline 8 & Sulami & 70 \\
\hline 9 & Sri Lasmiyatun & 60 \\
\hline 10 & Sukarni & 50 \\
\hline 11 & Suprapti & 60 \\
\hline 12 & Sri Muryadi & 40 \\
\hline 13 & Romi Yulianto & 60 \\
\hline 14 & Waliman & 50 \\
\hline 15 & Sumino & 50 \\
\hline 16 & Ngadi & 60 \\
\hline
\end{tabular}

Peserta dari pengabdian ini terdiri dari 16 orang. Dari Tabel 1 tersebut menunjukan rata-rata penilaian 57,5. Dari hasil tersebut, diketahui bahwa pemahaman peserta terhadap kejenuhan oksigen dalam darah masih tergolong rendah.

Kegiatan pengabdian ini kemudian dilanjutkan dengan pemberian materi dan demo penggunaan oximeter. Gambar 1 menunjukan saat pemberian materi, sedang Gambar 2 menunjukan saat demo cara penggunaan oximeter. Teknis penggunaan oximeter dilakukan dengan menekan tombol on, hingga muncul indikator lampu led menyala, kemudian dipasangkan pada ujung jari telunjuk pasien dalam posisi rileks (dalam posisi duduk atau disarankan pada posisi berbaring), kemudian tunggu beberapa saat agar oximeter 
melakukan pembacaan. Layar akan menunjukan angka $\mathrm{SPO}_{2}$ yaitu kadar kejenuhan oksigen dalam darah dan juga hearth rate. Setelah muncul angka pada layer oksimeter maka dilakukan pembacaan, kadar kejenuhan oksigen normal adalah di atas $95 \%$, jika hasil pembacaan di bawah $95 \%$ terindikasi hepoksemia atau kekurangan oksigen dalam darah.

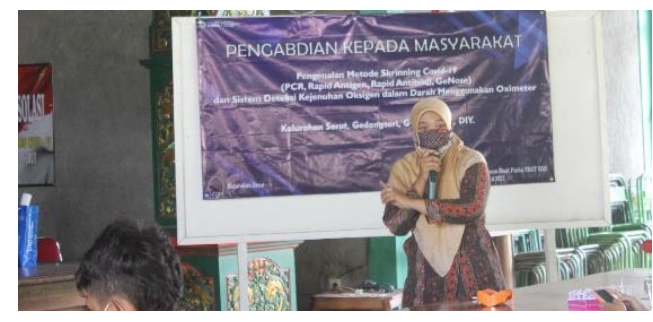

Gambar 1.Pemberian materi tentang kejenuhan oksigen dalam darah

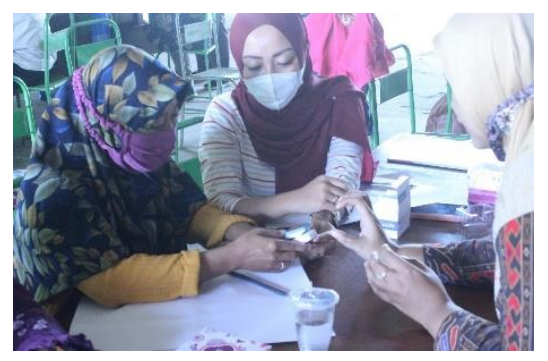

Gambar 2. Demo cara pemnggunaan oximeter

Adapun hasil dari pengukuran kadar kejenuhan oksigen dalam darah peserta pengabdian ditunjukan Tabel 2.

Tabel 2. Hasil pengukuran kejenuhan oksigen dalam darah peserta pengabdian

\begin{tabular}{|c|l|c|}
\hline No & \multicolumn{1}{|c|}{ Nama Peserta } & $\begin{array}{c}\text { Kejenuhan oksigen } \\
\text { dalam darah }\end{array}$ \\
\hline 1 & Nana & 98 \\
\hline 2 & Sigit Purnomo & 99 \\
\hline 3 & Triyono & 97 \\
\hline 4 & Nurul Hidayah & 98 \\
\hline 5 & Muji Rahayu & 98 \\
\hline 6 & Harsini & 97 \\
\hline 7 & Dariyem & 96 \\
\hline 8 & Sulami & 97 \\
\hline 9 & Sri Lasmiyatun & 98 \\
\hline 10 & Sukarni & 99 \\
\hline 11 & Suprapti & 98 \\
\hline 12 & Sri Muryadi & 97 \\
\hline 13 & Romi Yulianto & 99 \\
\hline 14 & Waliman & 98 \\
\hline
\end{tabular}

\begin{tabular}{|l|l|c|}
\hline 15 & Sumino & 96 \\
\hline 16 & Ngadi & 97 \\
\hline
\end{tabular}

Dari Tabel 2 tersebut terlihat bahwa hasil pengukuran oximeter tersebut di atas 95 semua, sehingga dapat disimpulkan bahwa peserta pengabdian kejenuhan oksigen darah dalam kondisi normal (DeMeulenaere, 2007; Lopez, 2012). Kegiatan pengabdian ini diakhiri dengan pemberian post test untuk mengetahui peningkatan pemahaman peserta setelah diberikan materi dan demo. Hasil post test ditunjukan pada Tabel 3.

Tabel 3. Hasil posttest peserta pengabdian

\begin{tabular}{|l|l|l|}
\hline No & Nama Peserta & Penilaian \\
\hline 1 & Nana & 100 \\
\hline 2 & Sigit Purnomo & 100 \\
\hline 3 & Triyono & 100 \\
\hline 4 & Nurul Hidayah & 100 \\
\hline 5 & Muji Rahayu & 100 \\
\hline 6 & Harsini & 100 \\
\hline 7 & Dariyem & 90 \\
\hline 8 & Sulami & 100 \\
\hline 9 & Sri Lasmiyatun & 100 \\
\hline 10 & Sukarni & 90 \\
\hline 11 & Suprapti & 100 \\
\hline 12 & Sri Muryadi & 100 \\
\hline 13 & Romi Yulianto & 90 \\
\hline 14 & Waliman & 100 \\
\hline 15 & Sumino & 90 \\
\hline 16 & Ngadi & 100 \\
\hline
\end{tabular}

Dari Tabel 3 tersebut terlihat bahwa nilai post-test yang peroleh jauh lebih besar dibandingkan pretest, rata-rata nilai posttest tersebut adalah 97,5.

\section{KESIMPULAN}

Kegiatan pengabdian masyarakat ini telah mengenalkan oximeter dan meningkatkan pengetahuan Satgas Covid-19 tentang kadar kejenuhan oksigen dalam darah, yaitu dari nilai rata-rata 57,5 meningkat menjadi 97,5. Di samping itu, Satgas Covid-19 memahami pentingnya deteksi tersebut bagi orang yang terinfeksi Covid-19 serta memahami 
penggunaan oximeter dan bagaimana menyimpulkan hasil yang tertera dalam oximeter tersebut.

\section{UCAPAN TERIMAKASIH}

Terimakasih kepada semua pihak yang sudah membantu dalam penyelesaian pengabdian ini yaitu LPPM UAD yang telah mendanai program pengabdian ini, Satgas Covid-19 Kalurahan Serut, dan Pemerintah Kalurahan Serut sebagai Desa Mitra

\section{DAFTAR PUSTAKA}

DeMeulenaere, S. (2007) 'Pulse Oximetry: Uses and Limitations', Journal for Nurse Practitioners. doi: 10.1016/j.nurpra.2007.02.021.

Lopez, S. (2012) Pulse Oximeter Fundamentals and Design, AN4327. doi: 10.1521/ijgp.2008.58.1.55.

Njoum, H. and Kyriacou, P. A. (2013) 'Investigation of finger reflectance photoplethysmography in volunteers undergoing a local sympathetic stimulation', Journal of Physics: Conference Series, 450(1). doi: 10.1088/1742-6596/450/1/012012.

Salamah, U. (2016) 'Rancang Bangun Pulse Oximetry Menggunakan Arduino Sebagai Deteksi Kejenuhan Oksigen Dalam Darah', Jurnal Penelitian Fisika dan Aplikasinya (JPFA).

Sinex, J. E. (1999) 'Pulse oximetry: Principles and limitations', American Journal of Emergency Medicine doi: 10.1016/S0735-6757(99)90019-0.

Smith Medical PM (2007) 'How can SpO 2 readings differ from manufacturer to manufacturer ?', Manual Pulse Oximetry, pp. 2-5.

Susilo, A. et al. (2020) 'Coronavirus Disease 2019: Tinjauan Literatur Terkini', Jurnal Penyakit Dalam Indonesia, 7(1), p. 45. doi: 10.7454/jpdi.v7i1.415.

Syafrida, S. and Hartati, R. (2020) 'Bersama Melawan Virus Covid 19 di Indonesia', SALAM: Jurnal Sosial dan Budaya Syar-i, 7(6), pp. 495-508. doi: 10.15408/sjsbs.v7i6.15325. 